\title{
Analisis Kelayakan Usaha Ternak Ayam Broiler yang diberi Pakan Komersil yang Substitusi dengan Amtabis
}

(Finances Feasibility Analysis on Broiler Commercial Production which Using Fermented Amtabis to Substitute Partly Amount of Standard Commercial Feed)

\author{
Elvira Rosa ${ }^{1}$, Sitti Wajizah ${ }^{1}$, Mira Delima ${ }^{1}$ \\ ${ }^{1}$ Program Studi Peternakan, Fakultas Pertanian, Universitas Syiah Kuala
}

\begin{abstract}
Abstrak: Penelitian tentang Analisis Kelayakan Usaha Ternak Ayam Broiler yang diberi Pakan Komersial di substitusidengan amtabisyang difermentasi dengan Aspergillus niger telah dilakukan di Laboratorium Lapangan Peternakan Fakultas Pertanian Universitas Syiah Kuala yang berlokasi di Desa Kopelma Darussalam Banda Aceh. Penelitian berlangsung selama 35 hari sejak tanggal 4 Desember 2015 sampai dengan tanggal 9 Januari 2016. Tujuan penelitian adalah untuk mengetahui tingkat kelayakan produksi dan biaya produksi usaha ternak ayam broiler dengan pemberian amtabis sebagai substitusi sebagian pakan. Parameter yang diamati adalah : biaya produksi, nilai pendapatan, keuntungan, dan kelayakan usaha. Hasil penelitian menunjukkan, peningkatan persentase substitusi amtabis mengakibatkan turunnya rata-rata biaya produksi yang berimplikasi pada meningkatnya nilai rata-rata penjualan, meskipun tidak melebihi nilai penjualan pada kontrol. Substitusi amtabis pada level $2 \%$ dan $4 \%$ diperoleh nilai B/C ratio lebih kecil dari satu, sehingga ransum tersebut tidak layak digunakan dalam usaha ayam broiler. Sedangkan substitusi amtabis pada level 6\% kembali meningkatkan nilai $\mathrm{B} / \mathrm{C}$ ratio sama dengan satu, sehingga ransum tersebut masih layak digunakan dalam usaha ayam broiler.
\end{abstract}

Kata Kunci: ayam broiler, ampas tahu, bungkil inti sawit, pakan fermentasi, amtabis, analisis kelayakan usaha

Abstrack: A research of finances feasibilityanalysison broiler commercial production which using fermented amtabis to substitutepartly amount of standard commercial feed was done on Animal Science Field Laboratory of Agriculture Department of Syiah Kuala University located at Kopelma County Darussalam Banda Aceh. The research was conducted from December 4th 2015 to January 9th 2016. The research purpose was to find finances feasibilityand production cost of broiler commercial production which using fermented amtabis to substitute partly amount of standard commercial feed. Parameters observed were productioncost, income value, profits and benefit cost ratio $(\mathrm{B} / \mathrm{C}$ ratio) analysis. The research concluded that partly substituting broiler standard commercial feed with fermented amtabis nor $2 \%$ and $4 \%$ was finnancially feasible $(\mathrm{B} / \mathrm{C}$ ratio $<1)$. However, partly substituting broiler standard commercial feed with $6 \%$ fermented amtabis was finnancially feasible $(\mathrm{B} / \mathrm{C}$ ratio $>1)$.

Keywords: broiler, ampas tahu, bungkil inti sawit, fermented feed, amtabis, finance feasibility analysis ransum ayam buras 


\section{PENDAHULUAN}

Saat ini, produksi ayam broiler menempati urutan pertama penyumbang ketersediaan daging ternak asal unggas Indonesia. Kontribusi daging asal Unggas mengalami peningkatan dari 20\% pada tahun 1970 menjadi 65\% pada tahun 2008 (Fadillah, 2013). Peningkatan kebutuhan terhadap daging ayam ini sejalan dengan laju pertumbuhan jumlah penduduk di Indonesia (Fadillah, 2013).

Rasyaf (2003) menyatakan bahwa ayam broiler adalah ayam pedaging yang dipelihara hingga 4-5 minggudengan bobot hidup dapat mencapai $2 \mathrm{~kg}$, dimana ayam ini paling efisien menghasilkan daging dibandingkan ayam yang lain.

Saat ini industri broiler menghadapi problema yang sangat mendesak, yaitu rendahnya efisiensi produktivitas. Hal ini dikarenakan biaya pakan pada industri broiler menempati 60 $70 \%$ dari total biaya produksi. Oleh karena itu, diperlukan suatu cara yang aplikatif untuk mengatasi permasalahan tersebut. Salah satu cara adalah memanfaatkan bahan pakan alternatif sebagai pakan ternak (Santoso, 2008).

Salah satu pakan hasil limbah industri pertanian yang digunakan dalam penelitian ini adalah amtabis. Amtabis merupakan pakan hasil fermentasi yang berbahan dasar ampas tahu dan bungkil inti sawit dengan menggunakan mikroba dari jenis kapang Aspergillus niger (A.niger)(Nurlianaet al.,2015).Pakan ini diharapkan mampu menekan biaya pakan yang tinggi dalam pemeliharaan ayam broiler. Pembuatan amtabis ini menggunakan metode fermentasi yang dipakai oleh Supriyadi(1995) dan kemudian dimodifikasi oleh Nurliana et al. (2015) dengan perlakuan sterilisasi basah. Salah satu mikroba yang lazim digunakan dalam fermentasi bahan pakan asal limbah adalah A.niger,karena pertumbuhannya relatif mudah, cepat, memiliki daya selulolitik, dan proteolitik yang tinggi, serta tidak menghasilkan mikotoksin (Darana 1995; Gras, 2008).

\section{Tempat dan Waktu Penelitian}

\section{MATERI DAN METODE}

Penelitian dilaksanakan di Laboratorium Lapangan Peternakan Fakultas Pertanian Universitas Syiah Kuala yang berlokasi di Desa Kopelma Darussalam Banda Aceh sejak tanggal 4 Desember 2015 sampai dengan tanggal 9 Januari 2016.

\section{Materi Penelitian}

Materi yang digunakan dalam penelitian ini adalah 100 ekor day old chick (DOC) ayam broiler, strain CP 707, produksi PT. Charoen Pokphand Jaya Farm, Medan.

\section{Alat-alat dan Bahan-bahan Penelitian}

Alat-alat yang digunakan dalam penelitian ini adalah kandang bersekat $100 \times 100 \mathrm{~cm}$, tempat pemberian ransum, tempat pemberian air minum, timbangan digital, terpal tempat mengaduk ransum, lampu pijar, label kandang, ember, thermometer, buku catatan, alat tulis, lampu minyak, sprayer,kipas angin, dan peralatan penunjang kandang.Bahan yang digunakan dalam penelitian adalah amtabis (ampas tahu dan bungkil inti sawit), ransum komersial broiler (511 Bravo produksi PT. Charoen Pokphand), Vitastress, Vaksin Gumboro, Vaksin ND, A. niger, litter dan air.Penelitian terdiri dari 4 perlakuan dan 5 ulangan. 


\section{Biaya Produksi}

Biaya produksi merupakan salah satu elemen yang penting dalam aktivitas produksi dari suatu perusahaan dalam pembentukan laba usaha. Biaya produksi menurut Mulyadi (2000) adalah "Biaya-biaya yang terjadi untuk mengolah bahan baku menjadi produk jadi yang siap dijual". Dengan adanya perencanaan biaya produksi, diharapkan dapat memperkirakan jumlah biaya bahan baku, biaya tenaga kerja dan biaya vitamin serta obatobatan yang perlu dialokasikan. Total biaya produksi pemeliharaan ayam broiler selama penelitian dapat dilihat pada Tabel 1.

Tabel 1. Total Biaya Produksi (Rp./ekor) Selama Penelitian

\begin{tabular}{ccccc}
\hline \multirow{2}{*}{ Total Biaya Produksi } & \multicolumn{4}{c}{ Perlakuan } \\
\cline { 2 - 5 } & $\mathrm{P} 0$ & $\mathrm{P} 1$ & $\mathrm{P} 2$ & $\mathrm{P} 3$ \\
\hline Penyusustan kandang & 493 & 493 & 493 & 493 \\
DOC & 5.600 & 5.600 & 5.600 & 5.600 \\
Pakan adaptasi & 6.656 & 6.656 & 6.656 & 6.656 \\
Pakan perlakuan & 26.587 & 25.206 & 24.681 & 24.530 \\
Vitamin & 585 & 585 & 585 & 585 \\
Vaksin & 690 & 690 & 690 & 690 \\
Tenaga kerja & 911 & 911 & 911 & 911 \\
\hline Total & 41.522 & 41.141 & 39.616 & 39.465 \\
\hline
\end{tabular}

Dari Tabel 1 dapat dilihat bahwa setiap unit penelitian memperlihatkan besaran biaya produksi yang berbeda. Hal ini disebabkan karena perbedaan biaya setiap faktor produksi dan setiap unit penelitian. Perlakuan P0 (Rp 41.522,-) memperlihatkan biaya produksi paling tinggi, sedangkan perlakuan P3 (Rp 39.465,-) memperlihatkan biaya yang produksi paling rendah. Rataan biaya produksi dari hasil penelitian pada masing-masing perlakuan dapat dilihat pada Grafik 1.

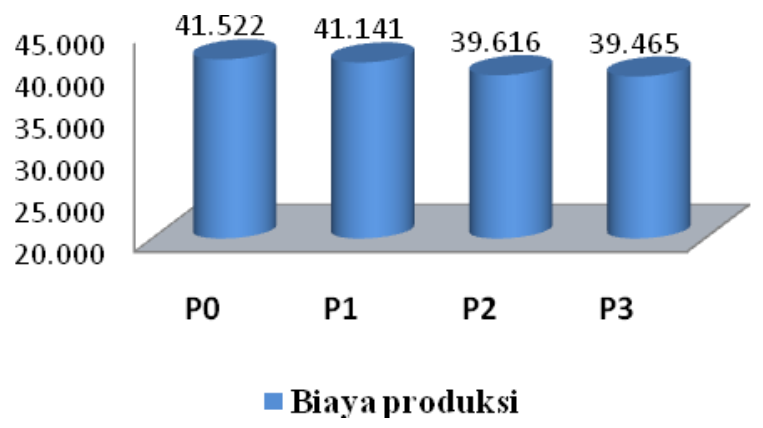

Gambar 1. Rataan Biaya Produksi pada Masing-Masing Perlakuan untuk 1 Ekor Ayam Selama Penelitian 


\section{Nilai Penjualan/ Hasil Produksi}

Hasil produksi yang dimaksud dalam penelitian ini adalah dalam bentuk karkas bersih dalam satuan kilogram. Harga jual per kilogram karkas adalah Rp. 30.000,--. Setelah dilakukan perhitungan maka didapatlah nilai penjualan dari setiap unit penelitiannya (Tabel 2).

Tabel2. Harga Penjualan Karkas Bersih (Rp/ekor) Ayam Penelitian

\begin{tabular}{ccccc}
\hline \multirow{2}{*}{ Ulangan } & \multicolumn{4}{c}{ Perlakuan } \\
\cline { 2 - 5 } & $\mathrm{P} 0$ & $\mathrm{P} 1$ & $\mathrm{P} 2$ & $\mathrm{P} 3$ \\
\hline $\mathbf{1}$ & 44.640 & 35.220 & 34.170 & 37.680 \\
$\mathbf{2}$ & 44.070 & 30.900 & 35.310 & 38.580 \\
$\mathbf{3}$ & 39.600 & 34.350 & 36.720 & 41.730 \\
$\mathbf{4}$ & 44.610 & 35.310 & 38.940 & 40.350 \\
$\mathbf{5}$ & 45.510 & 41.070 & 37.350 & 39.360 \\
\hline Total & 218.430 & 176.850 & 182.490 & 197.700 \\
\hline Rata-Rata & 43.686 & 35.370 & 36.498 & 39.540 \\
\hline
\end{tabular}

Dari Tabel 2. dapat terlihat rata-rata penjualan tertinggi terdapat pada perlakuan P0 (Rp. 43.686,-), dan harga jual terendah terdapat pada perlakuan P1 (Rp. 35.370,-). Rataan harga penjualan karkas bersih hasil penelitian pada masing-masing perlakuan dapat dilihat pada Grafik 2.

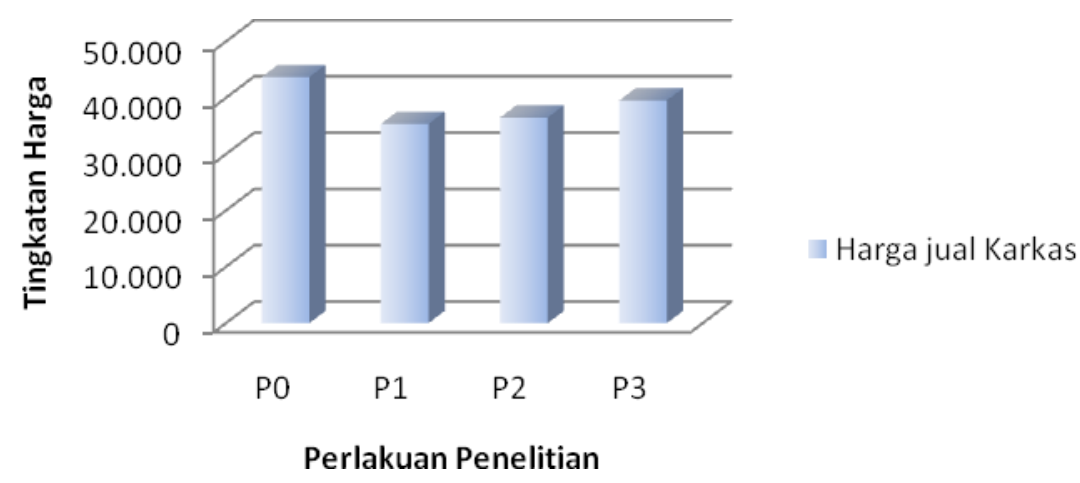

Gambar 2. Harga Penjualan Karkas Bersih (Rp/ekor) Ayam Penelitian

Nilai penjualan sangat dipengaruhi oleh berat karkas, semakin tinggi berat karkas maka nilai penjualan akan semakin tinggi. Menurut Soeparno (1992), Berat karkas ayam sangat dipengaruhi oleh konsumsi ransum, bangsa ayam, umur, berat hidup dan hormon.

\section{Keuntungan}

Keuntungan suatu perusahaan didapatkan dari hasil penjualan produk setelah dikurangi dengan biaya-biaya yang dikeluarkanperusahaan untuk memproduksi produk tersebut, dan suatu usaha bisa dikatakan untung apabila jumlah pendapatan yang diperoleh dari usaha tersebut lebih besar dari pada jumlah pengeluarannya (Soekartawi, 2003). Total keuntungan yang diperoleh selama penelitian dapat dilihat pada Tabel 3. 
Tabel 3. Total Keuntungan (Rp/ekor) Selama Penelitian

\begin{tabular}{ccccc}
\hline \multirow{2}{*}{ Ulangan } & \multicolumn{4}{c}{ Perlakuan } \\
\cline { 2 - 5 } & $\mathrm{P} 0$ & $\mathrm{P} 1$ & $\mathrm{P} 2$ & $\mathrm{P} 3$ \\
\hline $\mathbf{1}$ & 3.118 & -4.921 & -5.446 & -1.785 \\
$\mathbf{2}$ & 2.548 & -9.241 & -4.306 & -885 \\
$\mathbf{3}$ & -1.922 & -5.791 & -2.896 & 2.265 \\
$\mathbf{4}$ & 3.088 & -4.831 & -676 & 885 \\
$\mathbf{5}$ & 3.988 & 929 & -2.266 & -105 \\
\hline Total & 10.820 & -23.855 & -15.590 & 375 \\
\hline Rata-Rata & 2.164 & -4.771 & -3.118 & 75 \\
\hline
\end{tabular}

Menurut Harahap (2005) keuntungan merupakan angka yang penting dalam suatu usaha karena berbagai alasan antara lain: keuntungan merupakan dasar dalam perhitungan pajak, pedoman dalam menentukan kebijakan investasi dan pengambilan keputusan, dasar dalam peramalan keuntungan maupun kejadian ekonomi perusahaan lainnya dimasa yang akan datang, dasar dalam perhitungan dan penilaian efisiensi dalam menjalankan perusahaan, serta sebagai dasar dalam penilaian prestasi atau kinerja perusahaan.

\section{Analisis Benefit Cost Ratio}

Menurut Kadariah (1987), Jika Net B/C ratio >1, maka proyek tersebut layak untuk diusahakan karena setiap pengeluaran sebanyak Rp. 1 maka akan menghasilkan manfaat sebanyak Rp. 1. Jika Net B/C $<1$ maka proyek tersebut tidak layak untuk diusahakan karena setiap pengeluaran akan menghasilkan penerimaan yang lebih kecil dari pengeluaran.

Tabel 4. Analisis Benefit Cost Ratio (B/C Ratio) Ayam Penelitian

\begin{tabular}{ccccc}
\hline Perlakuan & Total Pendapatan & $\begin{array}{c}\text { Total } \\
\text { Produksi }\end{array}$ & $\begin{array}{c}\text { B/C } \\
\text { Ratio }\end{array}$ & Keterangan \\
\hline P0 & 43.686 & 41.522 & 1,05 & Layak \\
P1 & 35.370 & 41.141 & 0,86 & Tidak Layak \\
P2 & 36.498 & 39.616 & 0,92 & Tiadak Layak \\
P3 & 39.540 & 39.465 & 1,00 & Impas \\
\hline
\end{tabular}

Perhitungan $\mathrm{B} / \mathrm{C}$ ratio memperlihatkan bahwa pada tingkat perlakuan $\mathrm{P} 3$ (6\% amtabis) dalam ransum komersial layak untuk dilanjutkan sebagai usaha ayam broiler. Hal tersebut disebabkan karena B/C ratio yang diperoleh mencapai satu. Perlakuan P1 (2\% amtabis) dan P2 (4\% amtabis) menunjukkan nilai B/C kurang dari satu, yang artinya usaha ayam broiler yang menggunakan tingkat penambahan amtabis pada perlakuan tersebut akan mengalami kerugian jika dilanjutkan.

\section{KESIMPULAN}

Berdasarkan hasil penelitian dapat disimpulkan bahwa, peningkatan persentase substitusi amtabis mengakibatkan turunnya rata-rata biaya produksi yang berimplikasi pada meningkatnya nilai rata-rata penjualan, meskipun tidak melebihi nilai penjualan pada kontrol. Substitusi amtabis pada level $2 \%$ dan $4 \%$ diperoleh nilai $\mathrm{B} / \mathrm{C}$ ratio lebih kecil dari satu, sehingga ransum tersebut tidak layak digunakan dalam usaha ayam broiler. Sedangkan 
substitusi amtabis pada level $6 \%$ kembali meningkatkan nilai $\mathrm{B} / \mathrm{C}$ ratio sama dengan satu, sehingga ransum tersebut masih layak digunakan alam usaha ayam broiler.

\section{DAFTAR PUSTAKA}

Darana, S. 1995. Penggunaan Sorghum bicolour L. Mounch yang Difermentasi dengan Kapang Rhizopus oligosphorus dalam Ransum Ayam Broiler. Disertasi, Program Pascasarjana, IPB, Bogor.

Fadillah, R. 2013. Super Lengkap Beternak Ayam Broiler. Agromedia Pustaka, Jakarta

Gras, 2008. Aspergillus niger. http://www.cfsan.fda.gov/ rdb/opa-gras.html). Diakses tanggal 15 Februari 2016.

Harahap. 2005. Teori Akuntansi. PT. Raja Grafindo Persada, Jakarta.

Kadariah., 1987. Pengantar Evaluasi Proyek. Lembaga Penelitian Fakultas Ekonomi Universitas Indonesia, Jakarta.

Mulyadi. 2000. Akuntansi Biaya Edisi 5. Yogyakarta: Aditya Media.

Nurliana, S. Wajizah dan D. Masyitha. 2015. Pemberian Ampas Kedelai dan Serat Buah Sawit yang di fermentasi Aspergillus niger dalam Pakan untuk Peningkatan Produktivitas Ayam Petelur. Universitas Syiah Kuala, Banda Aceh.

Rasyaf, M. 2003. Beternak Ayam Pedaging. Penebar Swadaya, Jakarta

Santoso.2008.Pengaruh Penambahan Ekstrak Daun Katuk Terhadap Kualitas Telur dan Berat

Organ Dalam. Jurusan Peternakan, Fakultas Pertanian, Universitas Bengkulu, BengkuluJalan Raya Kandang Limun, Bengkulu.

Soekartawi. 2003. Teori Ekonomi Produksi.Jakarta : Raja Grafindo Persada.

Soeparno. 1992. Teknologi Pengawasan Daging. Institute Pertanian Bogor.

Supriyadi. 1995. Pengaruh tingkat penggunaan hasil fermentasi kulit ubi kayu oleh jamur Aspergillus niger dalam ransum terhadap performa ayam pedaging periode starter [skripsi]. [Bandung (Indonesia)]: Universitas Padjajaran. 